\title{
The International Chamber of Commerce Court of Arbitration
}

\author{
by \\ Michel Gaudet $\uparrow$
}

The expertise of the participants in this colloquium, who include public officials, entrepreneurs, and teachers and practitioners of international commercial law, makes it unnecessary to provide an extensive description of International Chamber of Commerce (hereinafter ICC) arbitration.

It is sufficient to recall here the characteristics that are unique to ICC arbitration. The ICC is a private institution, founded and financed exclusively by the enterprises that are its members and by the users of the services it offers. Its organization and rules have been designed specifically to meet the needs of international arbitration. The ICC's jurisdiction to arbitrate is unlimited so far as the geographic origins of the parties, the subject of disputes, the choice of arbitrators, the place of arbitration, and applicable law are concerned. The assistance of the Court and its Secretariat is available throughout the often complicated process of international commercial arbitrations.

For over 60 years ICC arbitration has faithfully embodied these three essential characteristics-providing arbitration that is international, geographically unlimited, and assisted. The ICC has constantly adapted its structure and its organs to evolving needs and circumstances through its regulations and practice. This effort is being vigorously continued. I plan to focus my remarks on what is changing at the present time.

\section{Change In Demand for ICC ARbitration}

Change is evident first in demand for ICC arbitration. The annual number of requests registered with the Court Secretariat has doubled in ten years. Close to 290 in each of the last three years, it was 339 in 1985, a 15 percent increase over the 1984 figure.

More than the total number of cases, their geographic distribution reveals a significant change. To be sure, Western Europe, the United States and Canada retain an important place in the use of ICC arbitration in terms of the number of parties, the arbitrators and the places of arbitration. But participation in these arbitrations by the other regions of the world continues

$\dagger$ Chairman, ICC Court of Arbitration. Translated by James Dunlap. 
to grow as their involvement in international trade grows. A key development has occurred over the last five years. In 1980, 137 parties to ICC arbitration came from regions other than Western Europe, the United States and Canada. By 1984, the figure had become 240, more than one party in three. Eighty-seven of them were in the position of plaintiff. At the same time, the number of arbitrators chosen from regions other than Western Europe, the United States and Canada grew from 30 in 1980 to 79 in 1984. Finally, the number of arbitrations located outside Western Europe, the United States and Canada went from 12 in 1980 to 22 in 1984. Observed as a whole, these different elements reveal a clear trend toward broader use of ICC arbitration. Thus the ICC Court of Arbitration is more and more often facing parties, arbitrators and laws that go beyond the scope of its traditional experience.

One of the major trends in ICC arbitration is the increasing presence of states and public enterprises. Their increasing participation in international trade involves them more frequently in disputes arising out of contracts they execute. Over the last two years, almost one party in six has been a state or a public enterprise. Some of these parties, still unused to distinguishing between exercising their institutional power and acting as commercial and industrial managers, find it difficult to behave as parties in a commercial arbitration proceeding. Thus the ICC is required to analyze new situations and develop measures that encourage satisfactory settlement of disputes.

After the geographic distribution of cases and the participation of states and public entities, a third subject that warrants comment is the complexity of litigation and procedures. Besides classic commercial transactions such as sale, transportation, or agency, large-scale international transactions based on a multiplicity of contracts and commercial partners cooperating in subcontracting and project financing are becoming more common. The scope of application of arbitration clauses, identification of the parties, determination of applicable laws, and definition of respective capacities and responsibilities require the Court and the arbitrators to make often delicate analyses.

In addition, the parties and their attorneys too frequently resort to procedural maneuvers, thus exacerbating legal complexities arising from contracts and rules of law. They try to take advantage of provisions concerning advance payment of costs (règlement des provisions), extension of time limits, organization of the proceedings (instruction des affaires), recourse to national courts, and even disqualification of arbitrators. But would the artful ingenuity of the legal profession not gain in both esteem and efficiency by applying itself to facilitating rapid and equitable settlements which encourage the growth of international transactions, rather than to discouraging this growth by permitting arbitration procedures to be long, costly and uncertain? In any case, the Court must for its part be in a position to reduce procedural maneuvering by adjusting its practice, and if need be its rules, and to offer effective assistance throughout arbitrations that are complex and of serious consequence to the parties. 


\section{I. Adaptation to New Circumstances}

The ICC has been working continually for ten years to adjust its services for the settlement of international commercial disputes to new circumstances. It has initiated or revived settlement mechanisms in addition to arbitration, which Sigvard Jarvin, the Court's General Counsel, discusses later in this Symposium. This area includes conciliation, expert technical advice, and readjustment of contracts.

In addition, reforms affecting the rules and practices of ICC arbitration have been adopted upon the initiative of the Court. The first stage was in 1980, when the Court secured a more flexible application of arbitration fee schedules and adopted its Internal Administrative Rules. These Internal Administrative Rules have clarified the practical application of certain provisions of the ICC Arbitration Rules, ${ }^{1}$ strengthened measures tending to assure the independence and impartiality of the Court and its members, and above all permitted the delegation of limited powers of decision to committees of the Court. Thanks to this step, the monthly sessions for deciding cases were tripled without exceeding either the capacities of the members of the Court, all nonremunerated, or the Secretariat's resources for preparation and implementation of decisions. At the same time periodic meetings of the Bureau, including the Chairman and Vice-Chairmen of the Court, have been inaugurated. The Bureau looks at the composition and independence of the Court and works out the main policies of the Court.

A second stage of reform began in 1984 and is continuing today. The composition of the Court and its Bureau has been broadened. The 43 members of the Court, including the Chairman and Vice-Chairmen, come from 37 countries, including 17 African, Latin American, Arab and Asian countries. The number of Vice Chairmen has been increased so that members from various regions of the world can make their contributions to the Bureau.

The Court Secretariat has also been reorganized and reinforced. A Secretary-General of the Court, Stephen Bond, has had overall responsibility for the Secretariat's activities since mid-1985. In particular, he supervises the five teams, each one under the direction of a Counselor, among which are distributed the cases brought before the Court. The General Counselor of the Court devotes the bulk of his time to research and information. The Secretariat's working tools have been modernized to include computer technology and telecommunications. The Secretariat endeavors to constantly improve the Court's organization and methods. Periodic discussions within the Court have been inaugurated, prepared by the Secretariat or by internal working groups. External sources have been called upon recently to report the reactions of users and experts in management problems to the present rules and practices of the Court. The studies being carried out at the present time will

1. The ICC Rules are printed infra in the Appendix to this issue of the International Tax \& Business Lawyer. 
likely not lead to changes in the fundamental characteristics of ICC arbitration, but rather to adjustments in the practice of the Court and its Secretariat.

\section{CoOperation in the DeVelopment of INTERNATIONAL ARBITRATION AROUND THE WORLD}

I have limited my remarks to changes directly affecting ICC arbitration. In closing I will touch on the attitude of the Court of Arbitration to the worldwide development of international commercial arbitration.

There has been a powerful display of interest in this subject both among governments and in business. Adhesion to international conventions which have been concluded over the last 30 years, participation in drafting model rules and laws studied at UNCITRAL, adoption or amendment of national legislation applicable to international arbitration, and support given to setting up regional, national or specialized arbitration centers all signify that states are not unaware of the usefulness of international arbitration in promoting development and external trade. After having successively tempted country after country, legal protectionism now appears unfavorable to economic growth and is becoming increasingly obsolete. Numerous national, regional or international organizations and associations, anticipating increased recourse to international arbitration, are proposing rules, and establishing or modifying centers for the carrying out of international arbitration. The last several years have thus been a period of intensive and sometimes apparently chaotic invention.

The ICC Court of Arbitration is closely watching this creative burst and participating in it with high hopes. It knows through experience the ignorance, fears and complications that deter industrialists and traders from foreign activity, especially in areas where differences of language, legal systems, and political or social ideas seem to set up formidable barriers. It is just these barriers which we must help public and private enterprise to overcome so that the economic exchanges and cultural interactions indispensable to peace and prosperity can multiply. Organizing a healthy and efficient way of settling international commercial disputes contributes to this development. A wide variety of approaches is useful, each making a specific contribution to the overall goal. Experience will gradually show which approaches among the flood of initiatives have lasting value.

Wishing to participate fully in this movement, the ICC Court is endeavoring to establish appropriate cooperative links with the arbitral institutions. The Court sometimes signs agreements, as it did in South Korea or India. Sometimes it takes part in regular group action, such as the joint colloquia with ICSID and the AAA, of which this is the third, or the periodic meetings of the East-West working group and seminars with international arbitral organs of the chambers of commerce of the countries signatory to the Convention for Mutual Economic Assistance. The fourth of these seminars is to be 
held in Bulgaria in late 1986. Sometimes, responding to the appeal of national organizations, the Court shares the lessons of its experience in arbitration colloquia, such as those held during 1985 in Thailand, India, Singapore, London, Seoul, Rio de Janiero and Quebec. In each of these meetings the Court has four essential concerns: organizing a regular exchange of information, taking inventory of research themes, working out appropriate educational activities, and making known the needs of international commercial arbitration to national and international public officials.

Given all of these efforts, you will readily understand how satisfying it is for the Court to be participating today in a joint colloquium uniting representatives of so many arbitral institutions from various regions of the world. 